\title{
Aplikasi Mobile WEB Map Service Pada Mobile Device Dengan SVGT
}

\author{
Sigit Priyanta, Ghulam Imanuddin dan Suci Karunia Prilistya
}

\begin{abstract}
Teknologi informasi geografi berkembang sangat pesat dalam beberapa dekade terakhir ini. Sekarang ini, WMS (Web Map Services) tidak hanya dapat menghasilkan gambar raster tetapi juga gambar vektor. Contohnya adalah SVGT (Scalable Vector Graphics Tiny) yang merupakan bagian dari SVG (Scalable Vector Graphics) yang digunakan pada piranti mobile device. Mahalnya biaya komunikasi antara handheld device dengan jaringan internet melalui GPRS (Global Pocket Radio System) menimbulkan sebuah masalah dalam penerapan aplikasi mobile mapping. Untuk mengeliminasi masalah tersebut, harus dibuat sebuah aplikasi mobile mapping yang dapat mentransfer data sekecil mungkin.
\end{abstract}

Didalam penelitian ini, dicoba untuk dibuat sebuah server pemetaan yang memanfaatkan teknologi SVGT dan XML. Kedua format data tersebut digunakan untuk menghasilkan data sekecil mungkin agar dapat menghemat biaya komunikasi antara klien dan server. Pada akhirnya, aplikasi yang dibangun akan menjadi sebuah server yang memiliki klien berupa handheld / mobile device.

Aplikasi ini dibangun dengan bahasa pemrograman PHP dan memanfaatkan database PostgreSQL beserta ekstensi PostGIS-nya pada sisi server dan J2ME (Java 2 Micro Edition) pada sisi mobile client. Aplikasi yang telah dibangun mampu untuk menampung peta jalan dari sebuah daerah, menampilkannya dalam format SVGT kepada klien, serta mencari rute terpendek antara dua buah jalan dengan menggunakan algoritma Floyd-Warshall. Mobile device sebagai client mempunyai beberapa fungsi utama, yaitu download map dengan format SVGT dari server, menyimpan map ke dalam record store, menampilkan map dan juga melakukan fungsi pan dan zoom terhadap map. Fungsi lainnya adalah searching atau mencari titik tertentu pada map sesuai dengan permintaan user, request path ke server untuk mendapatkan jalur terpendek antara dua titik, dan set mark atau menyimpan titik-titik pada peta yang telah diberi tanda oleh user.

Keywords - SVG, SVGT, Mobile Mapping, Web Map Services, J2ME, Java 2 Micro Editon.

S. Priyanta, Ilmu Komputer Fakultas MIPA Universitas Gadjah Mada, Yogyakarta 55281, e-mail : seagatejogja@ugm.ac.id

G. Imanuddin, Ilmu Komputer Fakultas MIPA Universitas Gadjah Mada, Yogyakarta 55281.

S. Karunia Prilistya, Ilmu Komputer Fakultas MIPA Universitas Gadjah Mada, Yogyakarta 55281.

\section{PENDAHULUAN}

\section{I.I LATAR BELAKANG MASALAH}

Teknologi informasi geografi berkembang sangat pesat dalam beberapa dekade terakhir ini. Teknologi informasi mengubah secara cepat penggunaan Geographic Information System (GIS) dari aplikasi dekstop klasik menjadi business service market. Dengan komputasi yang ada dimana-mana, beberapa tahun lagi setting berubah secara dramatis dan pasar GIS klasik akan berubah secara drastis [7].

Hingga tahun sembilanpuluhan, arsitektur GIS difokuskan pada lingkungan standalone (static). Arsitektur ini telah diubah agar aplikasi GIS pada workstation berubah menjadi aplikasi GIS pada mobile device [7].

Aplikasi mobile mapping bukan merupakan conventional GIS yang dimodifikasi agar bisa dioperasikan pada mobile device, melainkan merupakan sistem yang dibangun menggunakan paradigma baru yang fundamental.

Piranti mobile yang mendukung J2ME (Java 2 Micro Edition) menawarkan kepada pengguna dan pengembang sebuah open interface, sehingga pengembang aplikasi dan pengguna dapat men-download sesuai dengan perminataan. Sekarang ini $J 2 M E$ merupakan salah satu dari platform pengembangan mobile device yang paling terkenal [1].

Saat ini WMS (Web Map Service) tidak hanya dapat menghasilkan gambar raster tetapi juga gambar vektor. SVGT (Scalable Vector Graphics Tiny) merupakan bagian dari $S V G$ (Scalable Vector Graphics), yang digunakan pada mobile device. Format SVGT sangat cocok digunakan untuk mapping geografi, khususnya untuk mobile device yang mempunyai bandwidth yang sangat terbatas. Hal ini karena $S V G T$ merupakan gambar yang berbasis vektor dan mempunyai ukuran file yang kecil [1]. 


\section{I.II PERUMUSAN MASALAH} adalah :

Rumusan masalah dalam penelitian ini

1.Bagaimana pengembangan aplikasi WMS (Web Map service) menggunakan PHP dan progresql sebagai server, yang akan menghasilkan sebuah data peta yang berformat SVGT.

2.Bagaimana mengembangkan aplikasi mobile web map service menggunakan teknologi J2ME (Java 2 Micro Edition) dan SVGT (Scalable vector Graphics Tiny) untuk penentuan jarak terpendek.

\section{I.III BATASAN MASALAH}

Batasan masalah yang akan dibahas pada penelitian ini adalah :

Hasil dari penelitian ini, akan diujikan menggunakan emulator pada sistem lokal.

Server dapat menyajikan peta dan kemungkinan rute terpendek yang dapat dilalui antara dua tempat dalam satu wilayah.

Perhitungan rute terpendek dilakukan berdasarkan panjang suatu ruas jalan tanpa memperhitungkan arah jalan (searah atau dua arah).

Implementasi WMS pada sisi server menggunakan bahasa pemrograman PHP dan database PostgreSQL dengan ekstensi PostGIS.

Aplikasi client berjalan pada Mobile Device yang mendukung MIDP 2.0 dan CLDC 1.1, JSR 226 API yang merupakan API untuk menampilkan gambar 2D berbasis vektor seperti SVGT, dan GPRS(General Packet Radio Service) untuk koneksi internet.

\section{I.IV TUJUAN PENELITIAN}

Tujuan penelitian ini adalah untuk mengembangkan WMS (Web Map Services) server menggunakan PHP dan PostgreSQL yang dapat memberikan data peta dan rute terpendek antara dua tempat dalam format SVGT serta mengembangkan aplikasi client map atau peta pada mobile device menggunakan teknologi J2ME (Java 2 Micro Edition) dan SVGT (Scalable vector Graphics Tiny).

\section{I.V TINJAUAN PUSTAKA}

Hui [1], dalam tesisnya yang berjudul Design and Implement a Cartographic Client Application For Mobile Devices using SVG Tiny and J2ME mengulas pengembangan kartografi client untuk mobile devices menggunakan teknologi SVGT dan J2ME. Mobile device yang disimulasikan dalam komputer desktop mendapatkan data sebagai respon dari WMS berupa format vektor $(S V G)$ maupun raster $(P N G)$, melakukan parsing $X M L$ dan kemudaian menampilkan data tersebut. Dalam tesis ini juga terdapat pembahasan mengenai analisa dan desain dari struktur sistem seperti user interface dan code structure.

Liu [4], dalam tesisnya yang berjudul Mobile Map: A Case Study in the Design \& Implementation of a Mobile Application memaparkan desain dan implementasi aplikasi client/server pada mobile device. Selain itu juga dipaparkan teknik untuk menambah performance client pada sistem komputasi mobile client/server, serta mengidentifikasikan teknik yang paling menjanjikan, dan dapat diadaptasikan ke dalam aplikasi kepariwisataan.

Luqun [5], dalam sebuah jurnal yang berjudul A Research on Development of mobile GIS Architecture memaparkan tentang konsep dan arsitektur dari Mobile GIS. Dalam tulisan tersebut dijelaskan juga mengenai bagaimana cara komunikasi antara client dan server GIS, serta logic diagram dari Mobile GIS. Paper ini merepresentasikan four tier client/server Mobile GIS architecture.

\section{TEORI, MODEL DAN DESAIN}

\section{II.I SISTEM INFORMASI GEOGRAFI (SIG)}

Sistem informasi geografi merupakan sistem yang berbasiskan komputer yang digunakan untuk menyimpan dan memanipulasi informasi-informasi geografis. Literatur lain menyebutkan, sistem informasi geografi adalah sistem komputer yang digunakan untuk memasukkan (capturing), menyimpan dan menampilkan data-data yang berhubungan dengan posisi-posisi di permukaan bumi.

\section{II.II MODEL DATA SPASIAL}

Ada 2 macam pendekatan yang digunakan untuk merepresentasikan komponen data spasial yaitu model raster dan model vektor. 


\section{II.III POST GIS}

PostGIS adalah sebuah modul tambahan untuk RDBMS PostgreSQL server, yang digunakan untuk menangani data-data spasial beserta operasi-operasi spasial (Wikipedia,http://en.wikipedia.org/wiki/PostGis, 2006).

Objek spasial yang didukung oleh PostGIS adalah "Simple Feature" yang didefinisikan oleh OpenGIS Consortium (OGC). OpenGIS mendefinisikan dua cara untuk merepresentasikan objek spatial, yaitu WellKnown Text (WKT) dan Well-Known Binary $(W K B)$. Keduanya mengandung informasi tentang tipe objek beserta koordinatnya.

OpenGIS juga memerlukan format penyimpanan internal untuk objek spasial termasuk Spatial Referencing System Identifier (SRID). SRID ini diperlukan ketika membuat objek spasial untuk dimasukkan dalam database [6].

\section{II.1V MOBILE DEVICE}

Mobile device merupakan istilah yang sangat luas yang membungkus terminal informasi, alat-alat informasi, Personal Digital Assistant (PDA), Mobile phone dan lain sebagainya. Mobile device dapat diklasifikasikan secara luas ke dalam dua kategori yaitu :

1. Ponsel dengan kemampuan komputasi yang bertambah, termasuk tampilan gambar dan kemampuan interaksi via gambar (Smartphone, Communicator)

2. Komputer portable, yang dapat di-upgrade untuk kemampuan komunikasi suara (misalnya $P D A$ ).

Masing-masing Mobile device mempunyai Operation System (OS) yang memberikan interface dan mengendalikan sinkronisasi piranti. Sekarang ini ada empat $O S$ besar di pasaran, yaitu Symbian, Smartphone, Palm OS, dan Linux. Symbian digunakan oleh Nokia, Motorala dan Ericsson. Pada tahun 2005, Mobile phone yang telah menginstal Symbian OS menempati $51 \%$ dari smartphone di dunia [2].

\section{II.V KONSEP MOBILE MAPPING}

Dari sudut pandang tradisional, Geographics Information System (GIS) dapat didefinisikan sebagai sistem komputer yang digunakan untuk mengumpulkan, mensimulasi, memproses, mencari, menganalisa dan mendeskripsikan data geografi [5].

Mobile GIS merupakan sistem aplikasi dari sistem informasi geografi dan komunikasi Mobile yang mengintregasikan GPS, Wireless LBS, Mobile communication (seperti GSM, GPRS, dan CDMA, dan lain sebagainya) [5].

Sebagai pengganti software tradisional dan data yang besar, pengembangan Mobile GIS akan berubah menjadi jenis baru dari layanan dimana konsumen dapat mendapatkannya dari wireless internet, sebagai contoh Navigate service, Moving object monitor Service dan lain sebagainya.

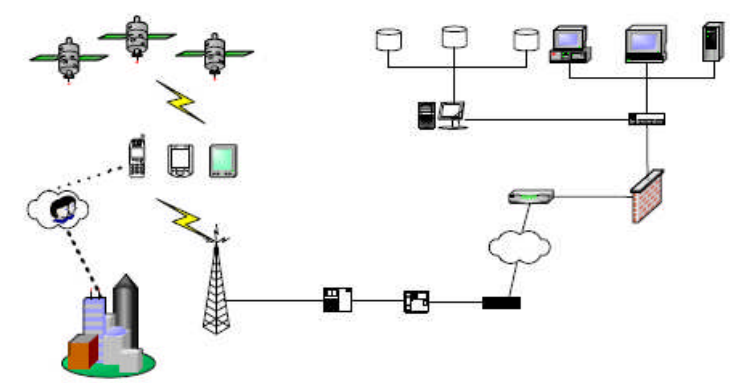

Gambar 1. Arsitektur dari of Mobile GIS (Luqun \& Minglu, 2004)

Ada tiga model aplikasi map pada Mobile device berdasarkan konektifitasnya, yaitu [7]. :

1. Offline mode (standalone), aplikasi dan data disimpan secara lokal seperti phone memory ataupun memory card.

2. Server connected mode, aplikasi diinstal secara lokal, tetapi semua data diambil dari centralized database yang disimpan di server.

3. Hybrid mode, beberapa data diinstal secara lokal dan frequently business data akan diambil dari server.

Masing-masing model mempunyai kelebihan dan kekurangan. Offline mode dapat bekerja sendiri (kapan saja dan dimana saja). Dalam mode ini, semua data harus diinstal terlebih dahulu, oleh karena itu ini akan menyediakan informasi yang dinamik. Di lain pihak, server connected mode lebih mahal dalam pengaksesan aplikasi dan biasanya tergantung pada kekuatan sinyal [7].

\section{II.V.I PLATFORM JAVA}

Sun microsystem telah mendefinisikan tiga platform Java yang masing-masing 
diarahkan untuk tujuan tertentu dan lingkungan komputasi yang berbeda-beda yaitu :

1. Standar Edition (J2SE) : Didesain untuk berjalan pada komputer dekstop dan komputer workstation.

2. Enterprise Edition (J2EE) : Dengan built-in mendukung untuk Servlet, JSP, dan XML, edisi ini ditujukan untuk aplikasi berbasis server.

3. Micro edition (J2ME) : Didesain untuk piranti dengan memori terbatas, layar display terbatas dan kekuatan pemrosesan yang juga terbatas.

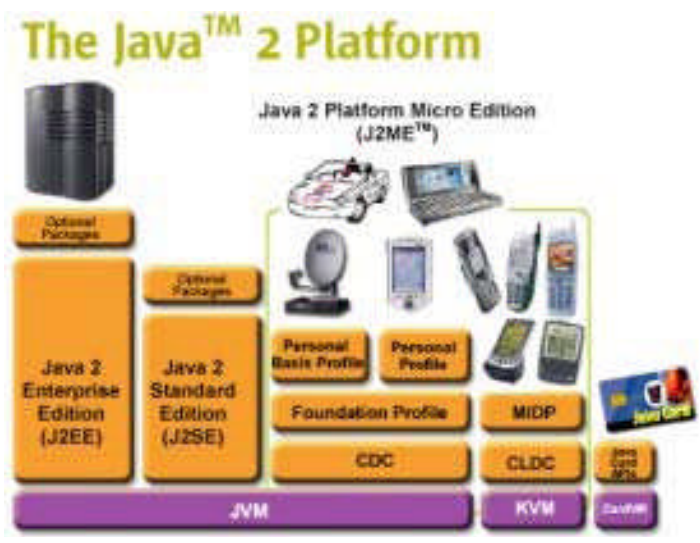

Gambar 2. Tiga platform Java 2

\section{II.V.II PENGENALAN SVG}

SVG (Scalable Vector Graphics) merupakan format file baru untuk menampilkan gambar dalam pengembangan web yang berbasis XML (eXtensible Markup Language). SVG berfungsi untuk menampilkan gambar 2 dimensi ke dalam kode $X M L[8]$.

$S V G$ menyediakan tiga tipe dari obyek gambar yaitu vector graphic shapes (misalnya path yang terdiri atas garis lurus dan kurva), multimedia (seperti gambar raster and video) dan text. Obyek gambar dapat di kelompokkelompokkan, diberi style dan digabung ke dalam obyek yang telah ada sebelumnya [8].

Kelebihan $S V G$ yang paling utama adalah gambar bisa diperbesar atau diperkecil tanpa mengurangi kualitas (scalable), karena dibuat berdasarkan metode vektor (vector), bukan pixel (seperti format gambar pada umumnya, GIF, JPEG dan $P N G$ ). Sehingga memungkinkan developer web dan juga designer untuk membuat gambar dengan kualitas yang tinggi [3].

\section{II.V.III SVG MOBILE}

Karena adanya perkembangan Mobile yang sangat pesat, ada permintaan untuk $S V G$ yang lebih cocok untuk lingkungan wireless, W3C mendefinisikan dua "Mobile profiles" dari SVG yaitu SVG Basic (untuk handset yang higher-end dan PDA) dan SVG Tiny (untuk smartphone dan piranti yang lower-end). SVG Tiny merupakan bagian dari $S V G$ Basic, yang merupakan bagian dari full SVG. SVG Tiny and SVG Basic dikenal sebagai "Mobile SVG" [9].

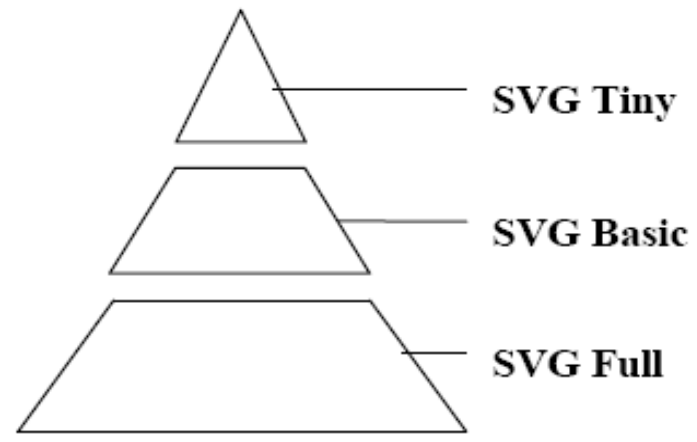

Gambar 3. Piramida dari SVG, SVGB dan SVGT (Hui, 2006)

SVG Mobile merupakan format vector graphic yang terdiri atas deskripsi geometrik dari semua bentuk dalam image dengan semua atributnya, termasuk warna, ukuran, dan ketebalan outline diantaranya. Mobile SVG adalah vendor-neutral dan open, berbasis XML dan didesain khusus untuk pengiriman dan tampilan wireless. Dibuat oleh W3C, Mobile SVG merupakan format standar untuk mendeskripsikan gambar vektor $2 \mathrm{D}$ dalam $X M L$ [9].

Keuntungan dari Mobile SVG adalah untuk encoding dan menampilkan content seperti animasi, map dan gambar yang interaktif. Scalability dari Mobile SVG memperbolehkan resizing gambar agar sesuai dengan ukuran atau resolusi layar atau printer tanpa kehilangan kualitas. Ini merupakan keuntungan dalam dunia wireless, dimana mobile device mempunyai bentuk dan ukuran yang kecil.

Keuntungan Mobile SVG untuk aplikasi mobile yang sensitif terhadap bandwidth, yaitu ukuran filenya lebih kecil dari bitmap, sehingga mengurangi waktu download melalui jaringan wireless [9].

\section{II.V.IV SVGT}

SVGT merupakan gambar yang berbasis $X M L$, source code untuk gambar SVGT tidak ditangani dalam format teks yang berubah-ubah, 
tetapi gambar SVGT atau dokumen SVGT adalah dokumen $X M L$ yang "well-formed".

Elemen $S V G$ terdiri atas semua elemenelemen yang lain. Ini merupakan elemen dokumen dari dokumen. Di dalam elemen tersebut, developer dapat menambah gambar dengan menggunakan elemen dan atribut shape yang standar yang disediakan oleh SVGT [1].

Obyek lain bisa ditempatkan di dalam obyek SVGT untuk membentuk graphic. Disediakan beberapa komponen dasar seperti rectangle, circle, ellipse, line, polyline dan polygon. Parameter style yang berhubungan juga didefinisikan. Selanjutnya, perintah yang lain yaitu path disediakan untuk mendeskripsikan garis dan kurva diantara titik. Sebagai tambahan, transformasi, masking, linking, temporal effect dan animasi juga memungkinkan [1].

\section{ANALISIS MASALAH}

\section{III.I ANALISIS KEBUTUHAN}

Elemen yang paling penting dalam sebuah map server yang sukses adalah adanya konten yang berkualitas serta pelayanan yang baik dan cepat terhadap klien. Masalah akses konten yang cepat bergantung pada kecepatan transfer media koneksi serta ukuran konten yang akan diberikan atau dikirim kepada klien. Server juga harus dapat melayani request peta dan request rute dari klien.

Dalam penelitian ini juga dibutuhkan sebuah klien untuk melakukan ujicoba server. Client merupakan aplikasi mobile yng dikembangkan menggunakan J2ME.

\section{III.II SPESIFIKASI KEBUTUHAN SISTEM}

\section{III.II.I KEBUTUHAN FUNGSIONAL}

Berdasarkan analisis kebutuhan di atas, maka aplikasi yang dibangun mempunyai kebutuhan fungsional sebagai berikut :

Aplikasi ini dibangun sebagai sebuah server pemetaan yang menampung data geografis berupa peta, dan dapat diakses oleh klien yang berupa handheld device.

Aplikasi dapat melakukan perhitungan jarak terpendek untuk rute yang diminta klien, dan mengembalikan kepada klien data rute yang dilalui dalam bentuk SVGT.

Aplikasi dapat membuat file berformat $S V G T$ dari data spasial yang terdapat dalam $D B M S$ PostgreSQL, yang nantinya file tersebut akan dikirim ke klien.

Aplikasi ini merupakan client yang berjalan pada mobile device yang dapat menampilkan map dengan format SVGT serta melakukan fungsi pan, zoom dan view all pada gambar tersebut.

Aplikasi dapat men-download map dengan format SVGT dari server. File yang didownload akan disimpan dalam database client.

1. Melakukan Request Path yaitu permintaan path yang menunjukkan jarak terpendek berdasarkan titik asal dan tujuan yang diberikan user .

2. Melakukan set mark atau menyimpan titiktitik pada peta yang telah diberi tanda oleh user.

\section{III.III ARSITEKTUR SISTEM}

\section{III.III.I ARSITEKTUR MODEL CLIENT SERVER}

Mobile Mapping merupakan aplikasi jaringan client-server. Aplikasi yang akan dibuat merupakan server tunggal. Klien terletak pada mobile device dengan memori, tempat penyimpanan, tampilan, network bandwith dan fungsionalitas yang kecil serta metode penginputan yang kurang. Server terletak pada komputer atau workstation dalam internet yang mempunyai memori dan storage yang besar serta kemampuan pemrosesan yang cepat.

Mobile device sebagai klien akan melakukan permintaan ke server, mendapat respon dari server dan kemudian menampilkan atau menyimpan file $S V G T$ yang diberikan oleh server.

Dalam aplikasi yang dibuat, server dapat menghitung dan mencari rute terpendek antara dua buah tempat yang ditentukan berdasarkan request dari klien, dan dapat menyajikannya dalam format $S V G T$.

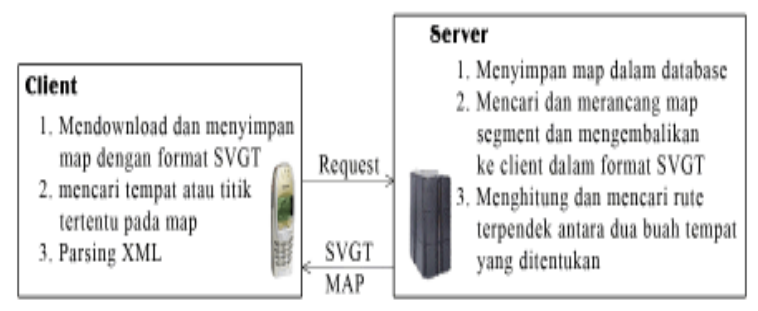

Gambar 4. Model mobile mapping client-server 


\section{III.III.II ARSITEKTUR SISTEM CLIENT}

Aplikasi yang dibuat difokuskan pada sisi client. Mobile device sebagai client mempunyai beberapa fungsi utama, yaitu download map dengan format SVGT dari server, menyimpan map ke dalam record store, menampilkan map dan juga melakukan fungsi pan dan zoom terhadap map. Fungsi lainnya adalah searching atau mencari titik tertentu pada map sesuai dengan permintaan user, request path jarak terpendek ke server, dan set mark atau menyimpan titik-titik pada peta yang telah diberi tanda oleh user.

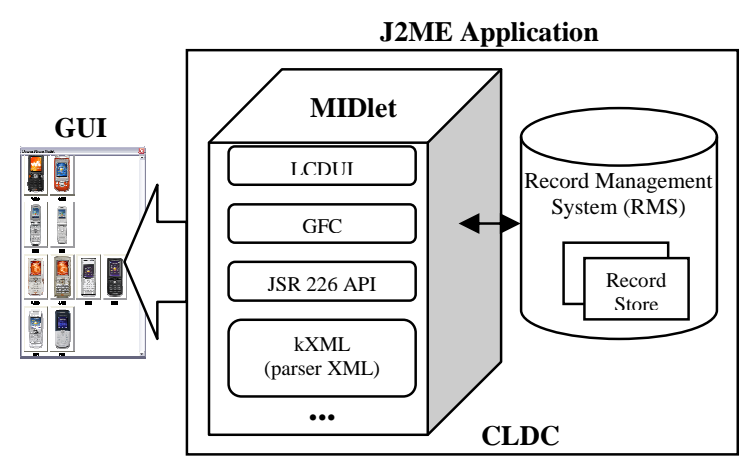

Gambar 5. Arsitektur Mobile mapping Client

\section{III.IV RANCANGAN PROSES WMS}

\section{III.IV.I DIAGRAM KONTEKS}

Diagram Alur Data (DAD) Konteks memperlihatkan sistem sebagai sebuah proses dan memiliki tujuan memberi pandangan umum mengenai sistem. Dari DAD konteks dapat dilihat proses interaksi dengan lingkungannya. Ruang lingkup sistem yang yang akan dibuat dapat diketahui prosesnya melalui Diagram Alur Data konteks yang ditunjukkan pada gambar 6 .

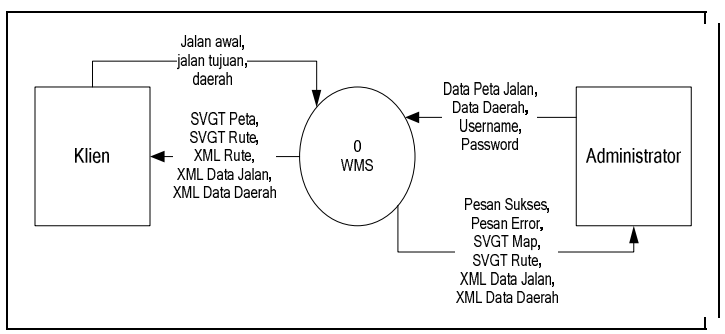

Gambar 6. Diagram konteks WMS

Diagram konteks WMS (Gambar 6) menggambarkan diagram arus data dasar. Dari diagram konteks di atas dapat dilihat 2 entitas luar yang berhubungan dengan $W M S$ yaitu klien dan administrator. Dimana klien dapat mengirimkan data jalan awal, data jalan akhir, dan data daerah kedalam sistem, dan menerima data $S V G T$ peta jalan, $S V G T$ data rute, $X M L$ data rute, $X M L$ data daerah, dan $X M L$ data jalan dari sistem. Administrator dapat memasukkan data berupa peta jalan dan data daerah kedalam sistem, dan menerima pesan sukses dan error dari sistem, tampilan peta yang diinput dalam format SVGT, tampilan rute dalam format SVGT, data daftar daerah, serta data daftar jalan.

\section{III.IV.II FLOWCHART PROSES}

\section{III.IV.II.I FLOWCHART PROSES PRA KALKULASI}

Proses ini digunakan untuk menghitung bobot dan rute terpendek antara dua jalan dalam daerah yang ditentukan. Pertama, proses akan meminta input nama daerah yang akan diproses. Kemudian, proses akan mengecek apakah data bobot sudah ada atau belum. Jika belum maka akan dibuat data bobot terlebih dahulu. Jika sudah ada, proses akan me-load data jalan dalam daerah tersebut dari database.

Kemudian, untuk setiap pasangan jalan yang ditentukan, dicari rute dan jarak terpendeknya. Hasilnya akan disimpan ke dalam tabel tbRute. Gambaran flowchart dari proses ini ditunjukkan pada gambar 7 .

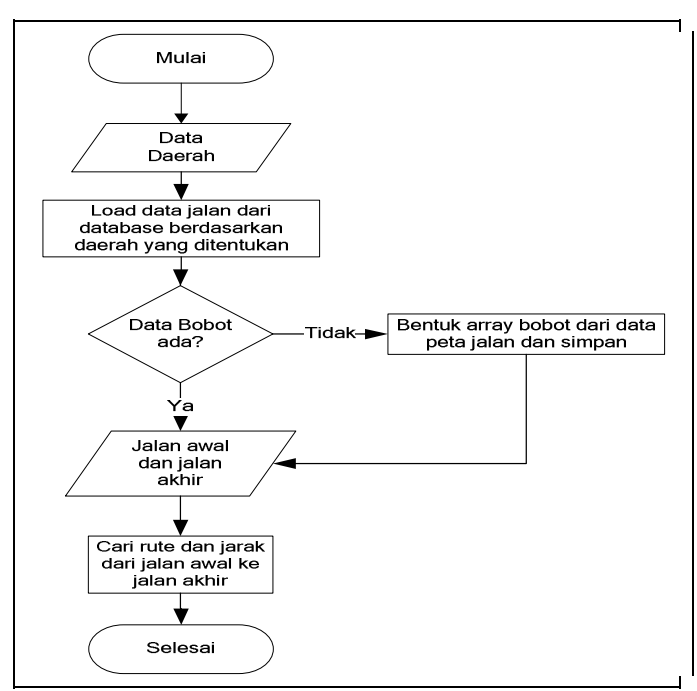

Gambar 7. Flowchart proses pra-kalkulasi

\section{III.IV.II.II FLOWCHART PROSES PENENTUAN RUTE JALAN}

Proses ini berguna untuk menjawab request dari klien yang ingin menentukan rute terpendek antara dua buah tempat. Pertama, proses akan me-load semua data jalan dari tabel 
tbJalan dan data rute dari tbRute. Selanjutnya diload juga data bobot dari file bobot sesuai dengan daerah yang ditentukan.

Lalu proses akan meng-ekstrak informasi tempat awal dan tempat tujuan dari URI yang diberikan user. Selanjutnya proses akan mencari apakah rute tersebut ada dalam tabel rute. Jika iya, maka data rute tersebut diambil, disusun, dan ditulis kedalam format $S V G T$ dan $X M L$.

Namun jika data rute yang diminta belum ada, maka proses akan melakukan perhitungan jarak terpendeknya. Ketika hasil perhitungan jarak terpendek didapatkan, maka hasil tersebut akan disimpan dalam database dan dikembalikan pada user yang me-request. Gambaran flowchart dari proses penentuan rute jalan ini ada pada gambar 8 dibawah ini.

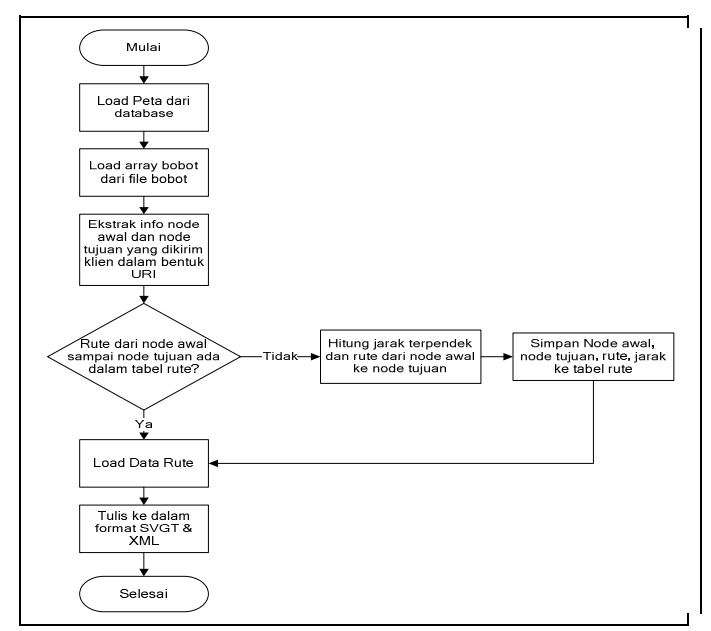

Gambar 8. Flowchart proses penentuan rute jalan

\section{III.IV.III USE CASE DIAGRAM}

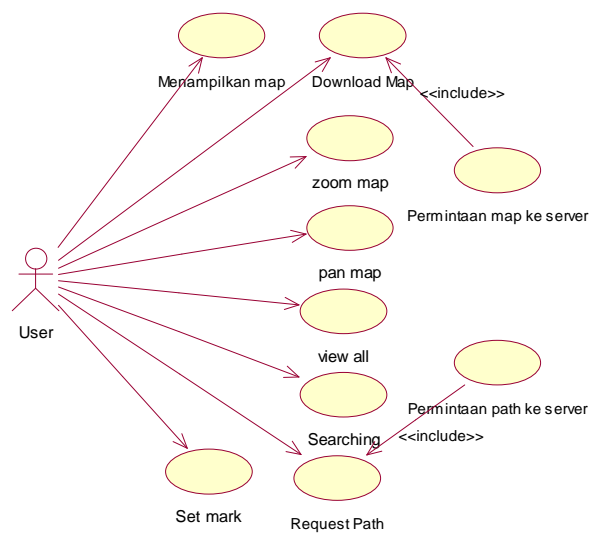

Gambar 9. Use case diagram

Use case diagram diatas memodelkan perilaku (behavior) dari sistem dan subsistem pada mobile mapping. Dalam diagram tersebut terdapat sebuah aktor yaitu pengguna (user) dan sepuluh use case yaitu :

Menampilkan map dengan format SVGT

Melakukan download map dengan format SVGT dari server

Melakukan permintaan map ke server

Melakukan penggeseran (pan) terhadap map yang telah dibuka telah dibuka

Melakukan zoom terhadap map yang

Menampilkan map secara keseluruhan (view all) terhadap map yang telah dibuka

Melakukan pencarian(searching) dan menampilkan tempat atau titik tertentu pada map sesuai dengan permintaan user .

1. Melakukan Request Path dari titik asal dan tujuan tertentu.

2. Melakukan permintaan path yang menunjukkan jarak terpendek berdasarkan titik asal dan tujuan yang diberikan user .

3. Melakukan set mark atau menyimpan titiktitik pada peta yang telah diberi tanda oleh user.

\section{III.V RANCANGAN BASIS DATA WMS}

Aplikasi WMS server menggunakan database dengan rancangan berikut :

Tabel 1. Tabel tbDaerah

\begin{tabular}{|l|l|}
\hline Field & Tipe \\
\hline Id & Int4 \\
\hline Nama_Daerah & Varchar(255) \\
\hline
\end{tabular}

Tabel 2. Tabel tbJalan

\begin{tabular}{|l|l|}
\hline Field & Tipe \\
\hline Gid & Int4 \\
\hline Nama_Jalan & Varchar(255) \\
\hline Length_kil & Float8 \\
\hline The_geom & Geometry \\
\hline Id_Daerah & Int4 \\
\hline
\end{tabular}

Tabel 3. Tabel Rute

\begin{tabular}{|l|l|}
\hline Field & Tipe \\
\hline Start_id & Int4 \\
\hline Finish_id & Int4 \\
\hline Rute & Varchar (255) \\
\hline
\end{tabular}




\section{III.V.I RELASI ANTAR TABEL}

Dari ketiga tabel diatas, dapat dibentuk relasi dari tabel-tabel tersebut. Relasi yang terjadi adalah antara tbDaerah dan tbJalan pada tbDaerah.id = tbJalan.id_daerah, tbRute dan tbJalan pada tbRute.start_id = tbJalan.gid dan tbRute.finish_id = tbJalan.gid. adapun diagram relasinya seperti pada gambar 10 .

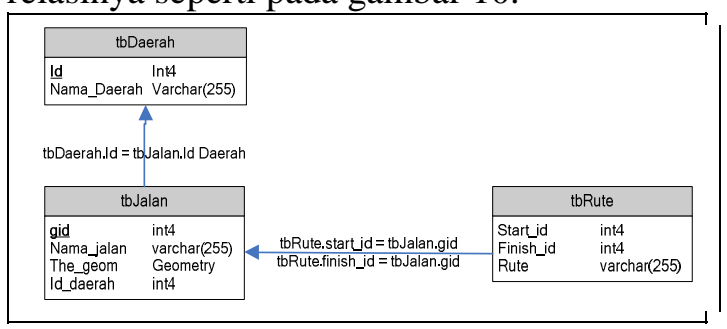

Gambar10. Relasi antar tabel yang terbentuk

\section{III.V.II RANCANGAN DATABASE MobILE DEVICE}

Karena keterbatasan mobile device, aplikasi mobile mapping yang akan dibangun menyimpan map dan data index pencarian dalam sebuah database sederhana menggunakan $R M S$ (Record Management System) yang terdapat pada $J 2 M E$ yang merupakan record-oriented database. Data yang diperlukan dalam aplikasi ini disimpan dalam record store yang terdiri atas record. Masing-masing record terdiri atas record id dengan tipe integer yang merupakan primary key dalam database, dan array of bytes untuk menyimpan data.

MIDlet yang akan dibuat mempunyai tiga macam record store yaitu record store untuk menyimpan map, record store untuk menyimpan index dan record store untuk menyimpan titiktitik pada map yang telah diberi tanda oleh $u s e r$.

Pada saat proses download map, file map yang di-download disimpan dalam record store map. Nama map sesuai dengan nama yang diberikan oleh server. Kemudian file map diparsing dan data jalan disimpan dalam record store index.

\section{III.V.III RECORD STORE MAP}

Record store map terdiri atas tiga kolom yaitu ID, idDaerah, mapName dan mapFile. ID merupakan record id yang dibuat oleh RMS secara otomatis. idDaerah merupakan ID yang diberikan server, mapName merupakan nama dari map dan mapFile berisi file SVGT. Ketiga kolom terakhir ini bertipe array of byte. Jumlah record dalam Record store ini dibatasi lima buah dan setiap record bersifat unik artinya satu dengan yang lain tidak boleh memiliki data yang sama. Hal ini dimaksudkan untuk menghemat memory mobile device.

Tabel 4. Record store map

\begin{tabular}{|l|l|l|l|}
\hline IDMap & idDaerah & MapName & MapFile \\
\hline & & & \\
\hline
\end{tabular}

\section{III.V.IV RECORD STORE INDEX}

Record store yang kedua adalah record store index yang terdiri atas empat kolom yaitu ID, StreetName, $x$, dan $y$. ID merupakan record id, indexName menyimpan nama jalan, $\mathrm{x}$ menyimpan absis dari jalan dan y menyimpan ordinat dari jalan. Jumlah record store index sesuai dengan jumlah map yang disimpan dan namanya sesuai dengan nama map yang bersangkutan.

Tabel 5. Record store index

\begin{tabular}{|l|l|l|l|}
\hline ID & indexName & $\mathrm{x}$ & $\mathrm{y}$ \\
\hline & & & \\
\hline
\end{tabular}

\section{III.V.V RECORD STORE MARK}

Record store yang ketiga adalah record store mark yang terdiri atas empat kolom yaitu ID, markName, $x$, dan $y$. ID merupakan record id, markName menyimpan nama jalan, $\mathrm{x}$ menyimpan absis dan y menyimpan ordinat dari titik. Jumlah record store mark sesuai dengan jumlah map yang disimpan dan namanya sesuai dengan nama map yang bersangkutan.

Tabel 6. Record store mark

\begin{tabular}{|l|l|l|l|}
\hline IDStreet & markName & $\mathrm{x}$ & $\mathrm{y}$ \\
\hline & & & \\
\hline
\end{tabular}

\section{HASIL DAN ANALISIS}

\section{IV.I IMPLEMENTASI PROGRAM WMS (SISI} SERVER)

Aplikasi yang telah dibangun terdiri atas dua bagian utama, yaitu bagian user dan bagian administrator data. Pada bagian user, ada empat buah proses utama, yaitu proses lihat peta, cari rute, download daftar jalan, dan download daftar daerah. Pada bagian administrator terdapat lima proses utama, yaitu proses login, input peta, lihat peta, pra kalkulasi, dan logout. 


\section{IV.I.I PROSES LIHAT PETA}

Proses ini akan menghasilkan peta dari daerah yang ditentukan dalam format SVGT. Untuk mengakses halaman ini, klien dapat merequest halaman ini dengan alamat [alamat_server]/[skrip_path]/map.php?id=[id _daerah]. Dalam pengujian, digunakan server lokal. Jadi, untuk mengakses fitur ini, digunakan alamat : http://localhost/WMS/map.php?id=1. Dimana id daerah yang digunakan adalah satu, yang merupakan contoh data dalam penelitian ini, yaitu data jalan sebagian Kota Yogyakarta. Contoh tampilan dari halaman ini (pada browser) seperti pada gambar 11 .

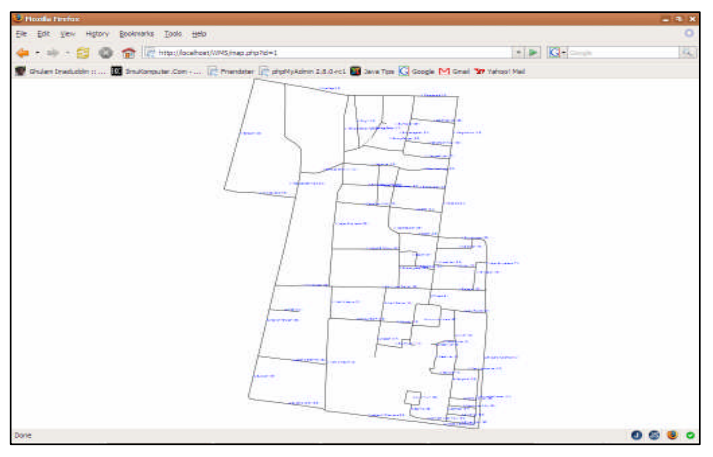

Gambar 11. Hasil SVGT peta pada browser

\section{IV.I.II PROSES CARI RUTE}

Proses ini akan menghasilkan rute jalan dari daerah yang diminta dalam format SVGT. Untuk mengakses halaman ini, klien dapat merequest halaman ini dengan alamat [alamat_server]/[skrip_path]/rute.php?start $=[$ id_jalan_mulai]

\section{\&finish=[id_jalan_akhir]\&id=[id_daerah].}

Dalam pengujian, digunakan server lokal. Jadi, untuk mengakses fitur ini, digunakan alamat http://localhost/WMS/rute.php?start=63\&finish= 43\&id=1. Contoh tampilan dari halaman ini (pada browser) seperti pada gambar 12.

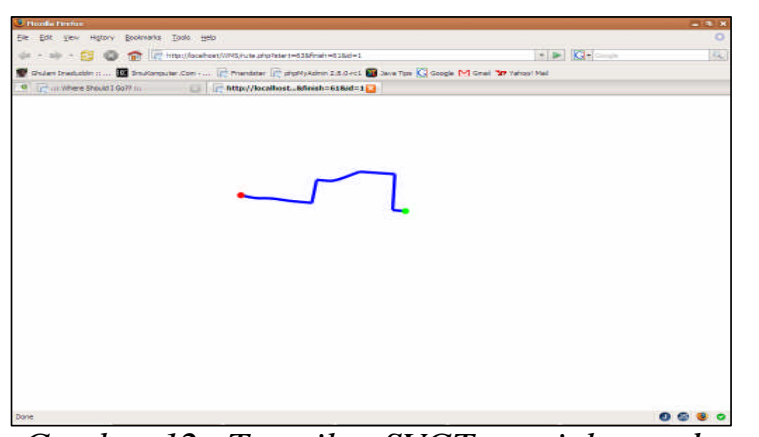

Gambar 12. Tampilan SVGT rute jalan pada browser

\section{IV.I.III DOWNLOAD DAFTAR DAERAH}

Proses ini akan menghasilkan daftar daerah yang ada dalam database. Untuk mengakses halaman ini, klien dapat me-request halaman ini dengan alamat [alamat_server]/[skrip_path]/list.php. Dalam pengujian, digunakan server lokal. Jadi, untuk mengakses fitur ini, digunakan alamat http://localhost/WMS/list.php. Contoh tampilan dari halaman ini (pada browser) seperti pada gambar 13.

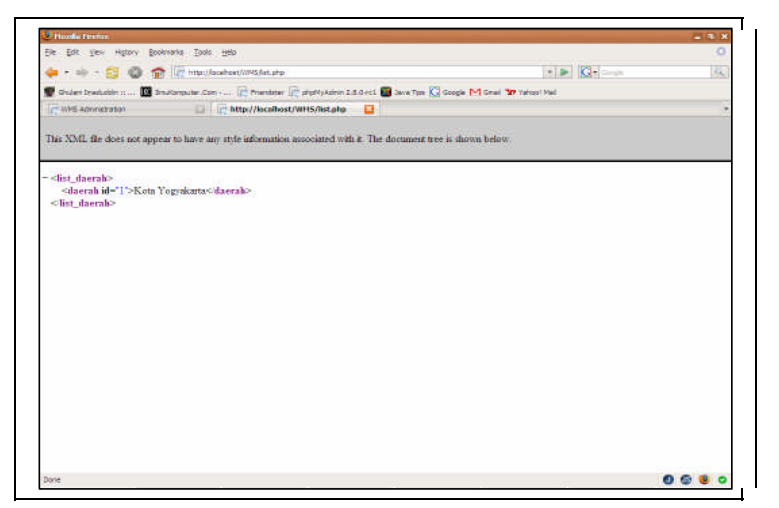

Gambar 13. Tampilan data daerah berformat XML pada browser

\section{IV.IIV DOWNLOAD DAFTAR JALAN}

Proses ini akan menghasilkan daftar jalan yang ada dalam database berdasarkan id daerah yang diminta. Untuk mengakses halaman ini, klien dapat me-request halaman ini dengan alamat : [alamat_server] /[skrip

_path]/list.php $\quad \mathbf{r}=\mathbf{j}$ jalan\&id=[id_daerah]. Dalam pengujian, digunakan server lokal. Jadi, untuk mengakses fitur ini, digunakan alamat http://localhost/WMS/list.php ?r=jalan\&id=1. Contoh tampilan dari halaman ini (pada browser) seperti pada gambar 14 .

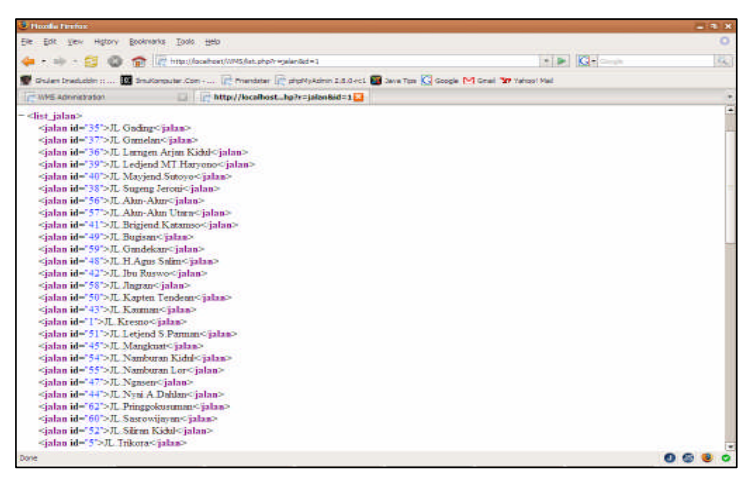

Gambar14. Tampilan XML data jalan pada browser 


\section{IV.I.V PROSES LOGIN ADMINISTRATOR}

Proses ini digunakan untuk masuk kedalam menu administrasi data peta. User harus memasukkan username dan password yang sesuai untuk dapat masuk. Proses Input Peta

Proses ini digunakan untuk menginputkan data peta jalan ke dalam database. Admin harus memasukkan data daerah dan data peta jalan dalam format SQL yang sesuai. Tampilan dari halaman login ini seperti pada gambar 15.

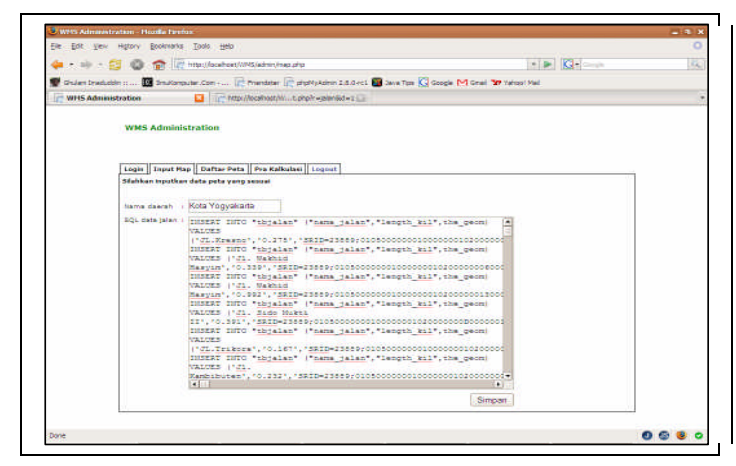

Gambar15. Tampilan halaman input peta

\section{IV.I.VI PRoses LIHAT DAFTAR PETA}

Proses ini mengambil semua data daerah dari database. Ketika link daerah diklik, maka akan ditampilkan peta daerah tersebut, seperti pada gambar 16.

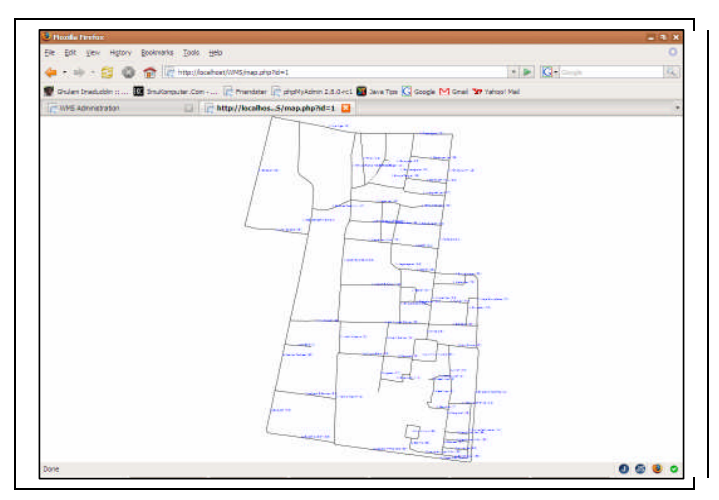

Gambar 16. Tampilan peta yang dipilih

\section{IV.I.VII FUNGSI-FUNGSI LAIN YANG DIGUNAKAN}

Dalam proses-proses diatas, digunakan fungsi-fungsi pendukung untuk membantu proses tersebut. Fungsi-fungsi pendukung yang dibuat adalah :

1. Fungsi untuk membuat header dari $X M L$

2. Fungsi untuk membuat DOCTYPE dari $S V G$

3. Fungsi untuk membuat Header dari $S V G$

4. Fungsi untuk mengambil viewbox dari peta

5. Fungsi untuk menentukan jarak antara dua titik dalam peta

6. Fungsi untuk menghitung bobot jalan pada peta

7. Fungsi untuk mengambil skala dari peta

8. Fungsi untuk menggambar path berdasarkan dua titik yang ditentukan

9. Fungsi Floyd-Warshall untuk menentukan jarak terpendek antara dua titik

Fungsi ini akan mencari semua pasangan node yang telah terboboti. Dari pasangan node tersebut akan dicari setiap jarak minimum dan rute-nya. Setelah itu, jarak dan rutenya akan dijadikan nilai kembalian dari fungsi ini. Adapun kode dari fungsi ini ditunjukkan pada gambar 17. 


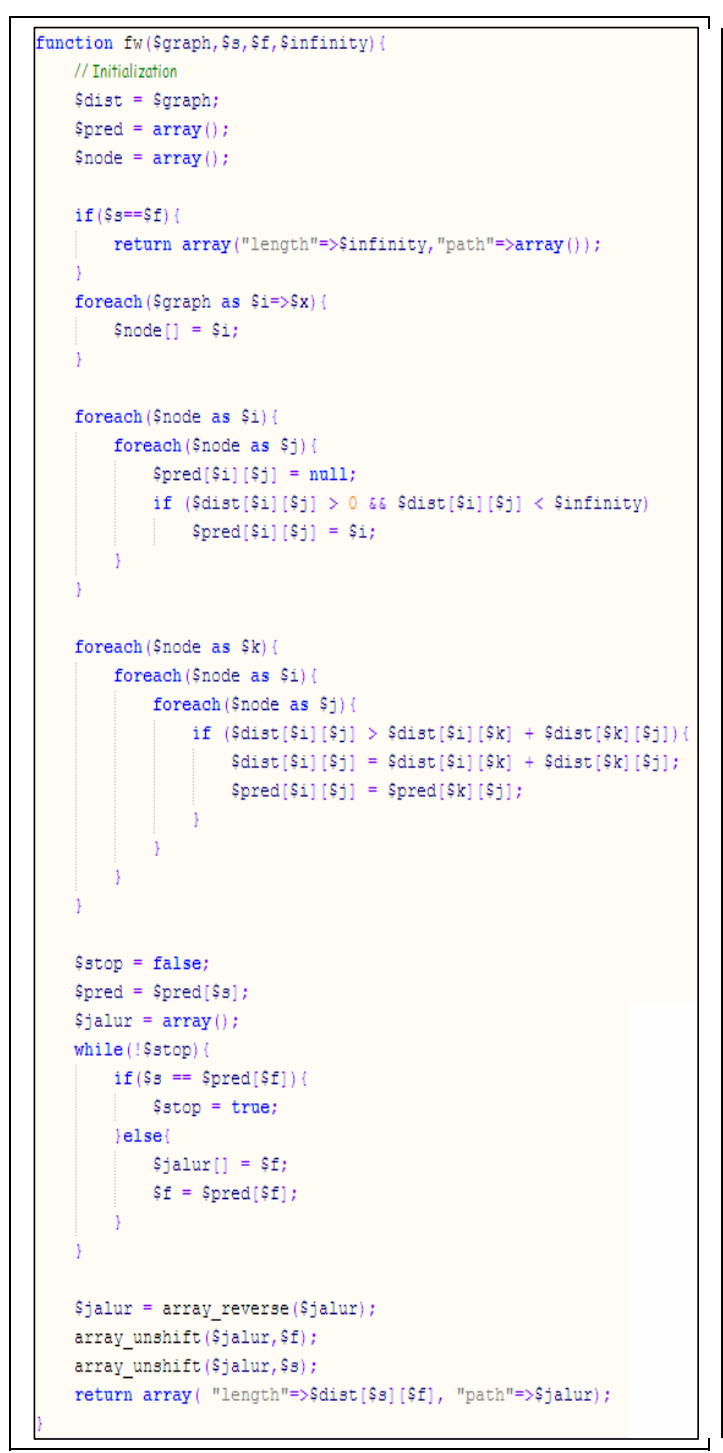

IV.II IMPLEMENTASI PRogram Sisi CliENT (J2ME)

Aplikasi yang telah dibangun terdiri atas sembilan belas class dengan class utama adalah class MobileMapping.

\section{IV.II.I MENU UTAMA}

Class yang berfungsi untuk menampilkan menu utama adalah class MobileMapping. Class tersebut merupakan class yang pertama kali dieksekusi ketika aplikasi dijalankan. Class tersebut merupakan turunan dari class MIDlet dan mengimplementasikan Interface Command Listener yang akan menampilkan lima menu utama dari aplikasi yang akan dibangun yaitu Open Map, Download, Help, About, dan Exit.

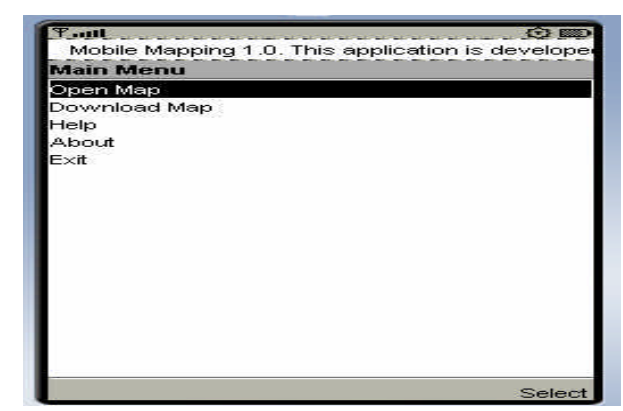

Gambar 18. Tampilan menu utama aplikasi Mobile Mapping pada emulator JWTK 2.5beta

\section{IV.II.II PENYIMPANAN DATA}

Fungsi penyimpanan pada aplikasi yang dibuat melibatkan empat class yaitu class DataReadWrite, MapReadWrite, IndexReadWrite dan MarkReadWrite. Hirarki dari class-class tersebut seperti pada gambar 19 .

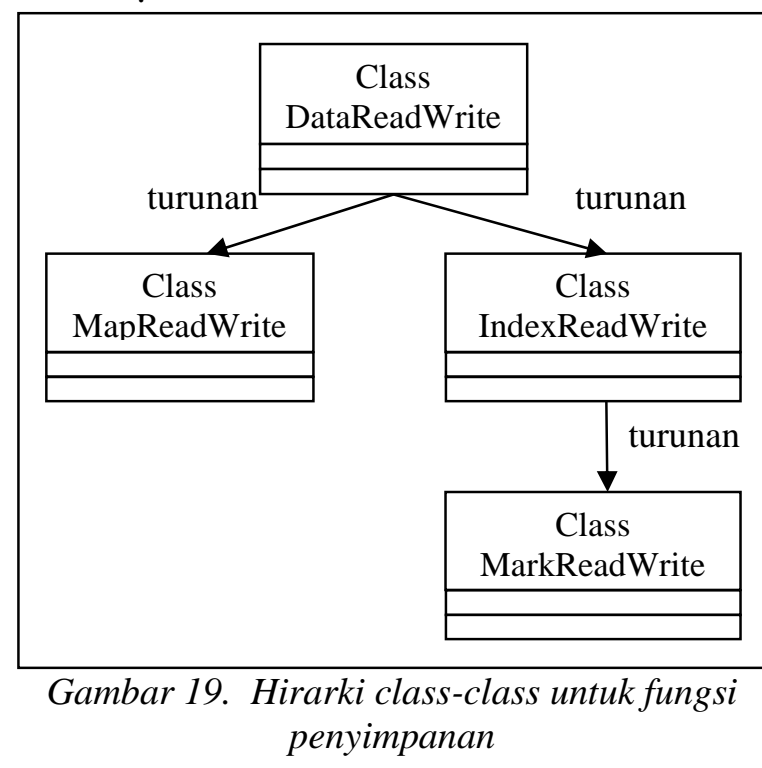

IV.II.III PENAMPILAN MAP YANG ADA PADA RECORD STORE

\section{IV.II.III.I CLASS MAP LIST SCREEN}

Class ini mengimplementasikan interface CommandListener dan berfungsi untuk menampilkan daftar nama-nama map yang terdapat dalam record store.

Method MapList() memberikan nilai kembalian List. Method membuat obyek List dengan item berupa nama semua map yang disimpan di record store dan tiga buah Command dengan label back, view dan delete. 


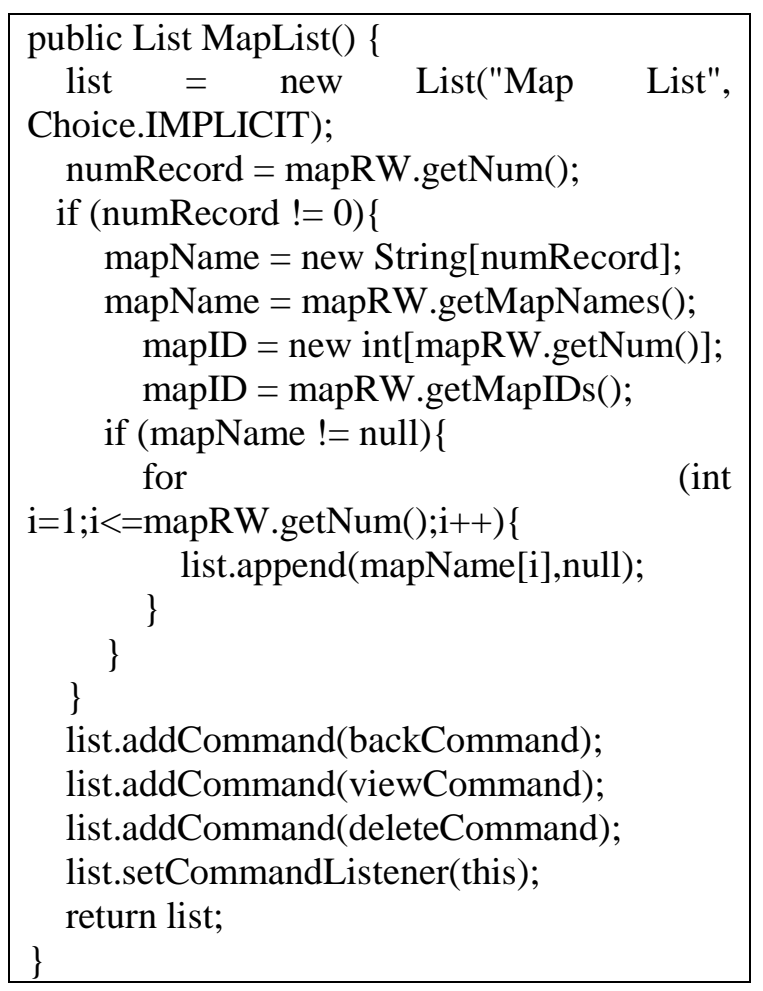

Gambar 20. Method MapList() pada class MapListScreen

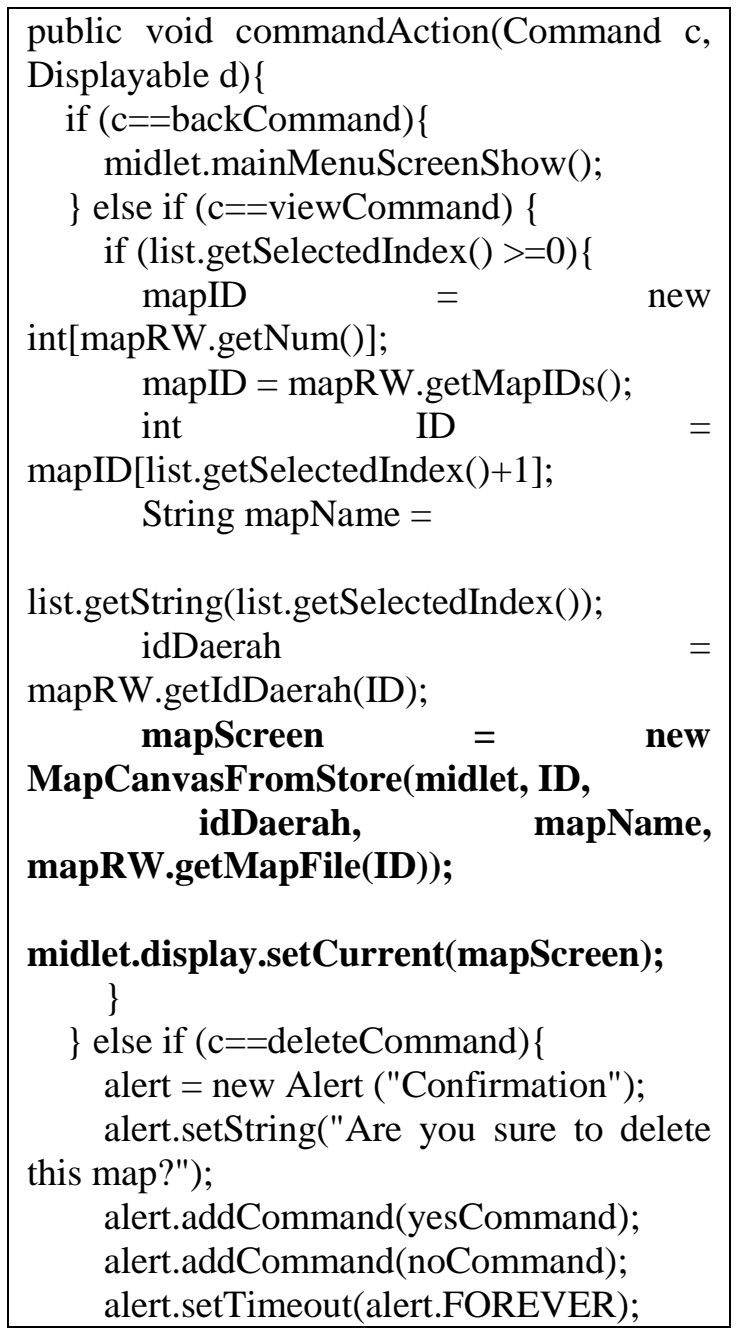

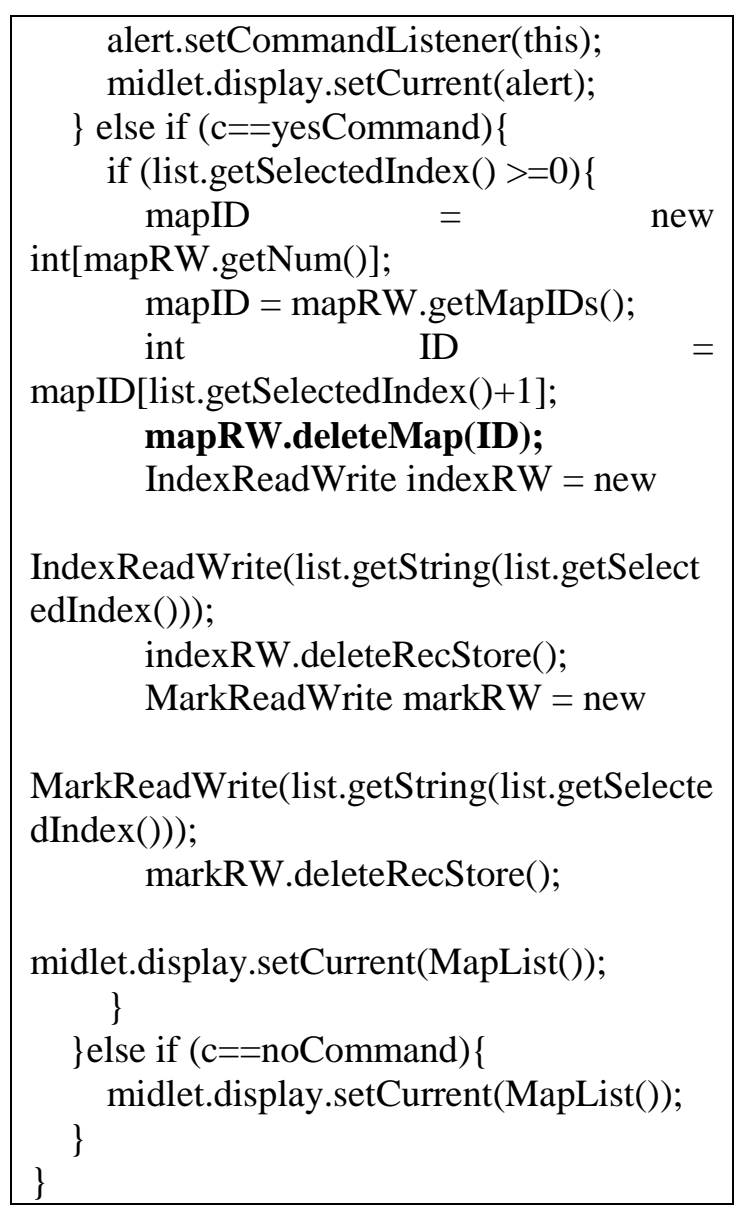

Gambar 21. Method commandAction(Command c, Displayable d) pada class MapListScreen

Method commandAction(Command c, Displayable d) yang merupakan implementasi dari class abstract CommandAction didefinisikan tindakan yang akan dilakukan jika ada Command yang dipilih oleh $u$ ser.

Jika dipilih viewCommand maka map yang dipilih akan ditampilkan. Jika deleteCommand dipilih maka akan dilakukan pemanggilan method deleteMap(ID) dari class MapReadWrite yang berarti map yang dipilih dihapus dari record store.

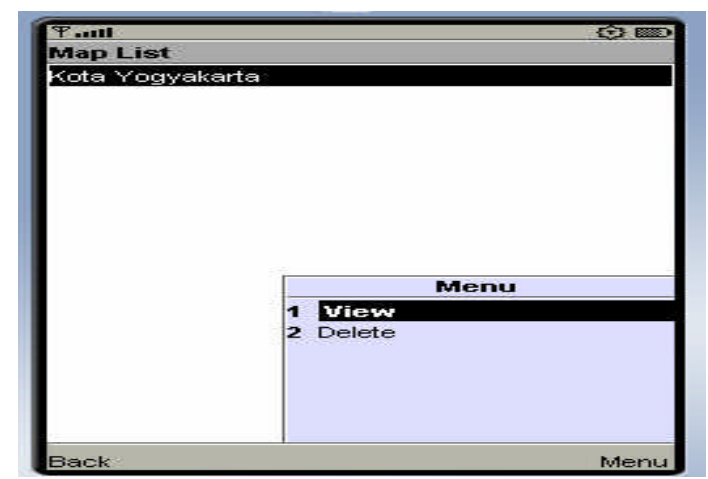

Gambar 22. Tampilan daftar map yang disimpan, pada emulator JWTK2.5beta 


\section{IV.II.III.II CLASS MAP CANVAS}

Class MapCanvas merupakan turunan dari class Canvas dan mengimplementasikan interface CommandListener. Class ini berfungsi untuk menampilkan map dengan format SVGT dan menampilkan perintah-perintah yang didefinisikan.

Gambar 23 merupakan tampilan map yang datanya diambil dari record store dengan enam pilihan menu. Emulator yang digunakan adalah pada emulator J2ME wireless toolkit 2.5 beta.

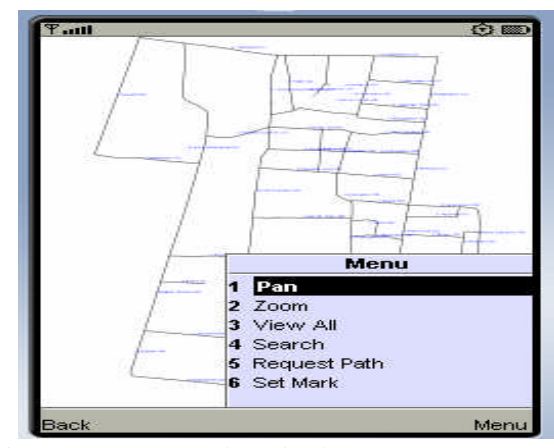

Gambar 23. Tampilan halaman view map pada emulator JWTK2.5beta

\section{IV.II.IV PAN (PENGGESERAN MAP)}

Class MapPan berfungsi untuk menggeser map yang ditampilkan. Class ini mengimplementasikan interface SVGEventListener yang mengirim event yang terjadi pada map SVGT, ke aplikasi.

\section{IV.II.V ZOOM (PERBESARAN MAP)}

Class MapZoom berfungsi untuk memperbesar atau memperkecil map yang ditampilkan. Class ini mengimplementasikan interface SVGEventListener seperti pada class MapPan.

\section{IV.II.VI SEARCHING (PENCARIAN) TEMPAT TERTENTU PADA MAP (CLASS SEARCH SCREEN)}

Class yang mengimplementasikan interface CommandListener ini menampilkan daftar tempat atau jalan yang terdapat pada map yang ditampilkan. Data yang ditampilkan diambil dari tabel jalan yang namanya sesuai dengan nama map yang bersangkutan.

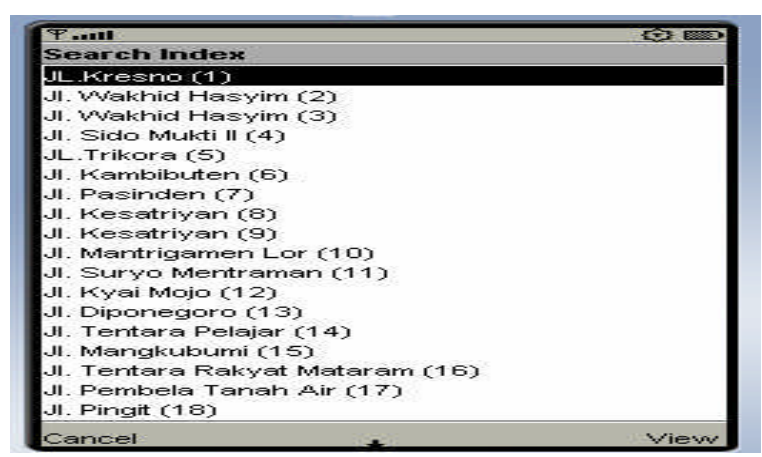

Gambar2 4. a Tampilan Search Path pada emulator JWTK2.5beta

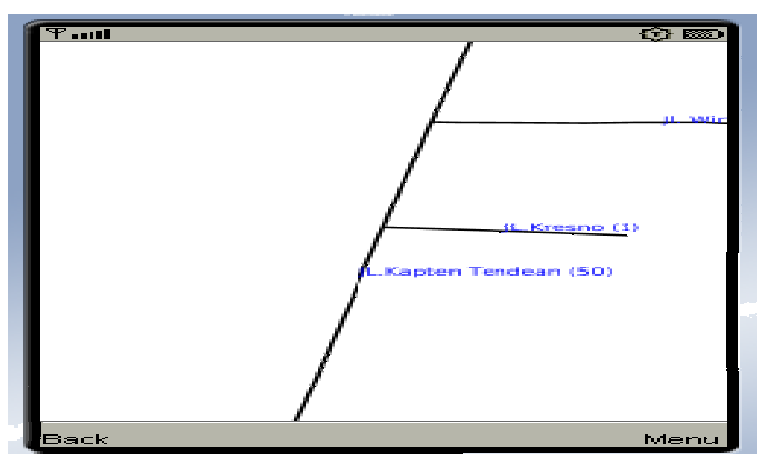

Gambar2 4. b Tampilan Search Path pada emulator JWTK2.5beta

\section{IV.II.VII REQUETH PATH}

Proses request path melibatkan dua class, yaitu class PathCanvas dan PathScreen dan sub proses yang dilakukan adalah sebagai berikut :

1. Melakukan request daftar jalan ke server mengirimkan ID map yang bersangkutan.

2. Melakukan parsing dokumen XML yang berisi daftar jalan yang merupakan respon dari server.

3. Melakukan request path jarak terpendek ke server dengan mengirim id jalan asal dan tujuan.

4. Menggabungkan data sebagai respon dari server dengan map SVGT yang bersangkutan.

5. Menampilkan hasil gabungan di atas ke layar.

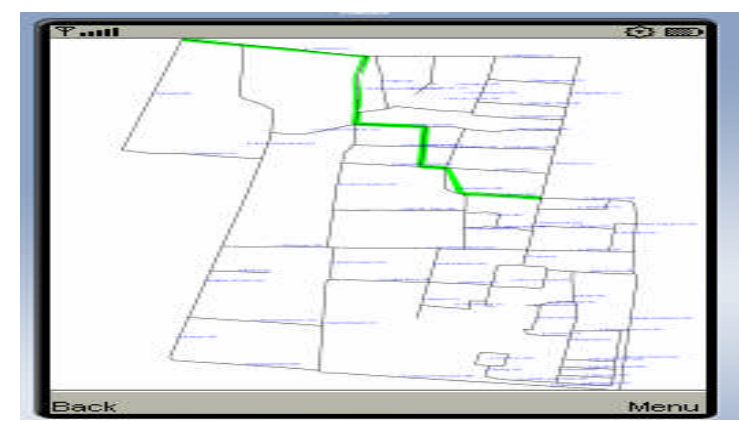

Gambar 25. Tampilan map hasil

RequestPath pada emulator JWTK2.5beta 


\section{IV.II.VIII FUNGSI SET MARK}

Pada aplikasi yang dibuat juga terdapat fungsi set mark yaitu fungsi agar user bisa menandai titik-titik tertentu. Satu map akan berelasi dengan satu record store yang menyimpan titik-titik tersebut.

\section{IV.II.VIII.I CLASS MAP MARK}

\begin{tabular}{|l}
\hline public MapMark(SVGImage inImage, \\
SVGAnimator inAnimator, MapCanvas \\
mapCanvas) \{ \\
this.svgMap = inImage; \\
this.animator = inAnimator; \\
this.canvas = mapCanvas; \\
pan = new MapPan(inImage, inAnimator, \\
mapCanvas); \\
this.document = svgMap.getDocument(); \\
this.root = (SVGSVGElement) \\
document.getDocumentElement(); \\
this.scale = \\
root.getBBox().getWidth()/root.getScreenBB \\
ox().getWidth(); \\
createPointer(); \\
root.appendChild(pointer); \\
\}
\end{tabular}

Gambar 26. Constructor pada class MapMark

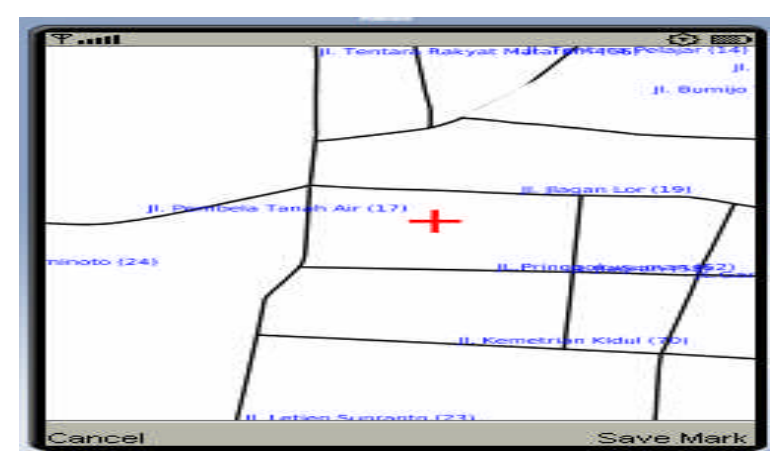

Gambar 27. Tampilan pointer set mark pada emulator JWTK2.5beta

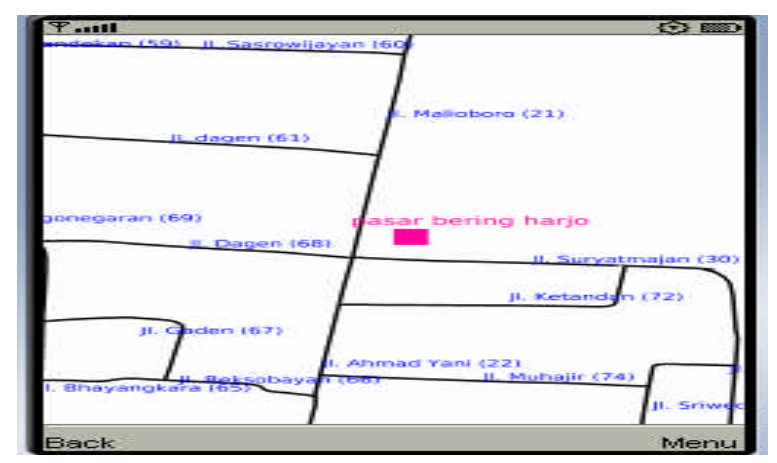

Gambar 28. Tampilan pointer hasil set mark pada emulator JWTK2.5beta

\section{IV.II.IX FUNGSI DOWNLOAD MAP}

\section{IV.II.IX.I CLASS DOWNLOAD SCREEN}

Class ini juga mengimplementasikan interface CommandListener. Jika dieksekusi, maka class ini akan mengirim permintaan data map ke server. Server akan merespon dengan mengirimkan daftar map yang disediakan server dengan format XML. Class ini akan melakukan parsing $X M L$ dan menampilkan data tersebut ke layar. Kemudian pilihan dari user akan dikirim ke server dan server akan merespon dengan mengirimkan map sesuai dengan permintaan.

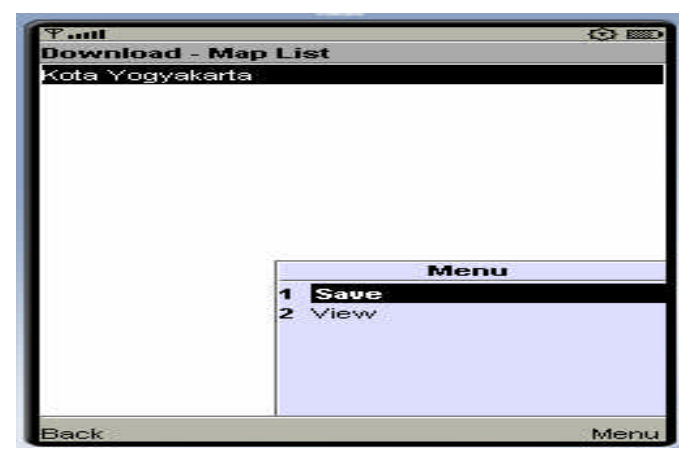

Gambar 29. Tampilan halaman download pada emulator JWTK2.5beta

\section{IV.II.IX.II CLASS MAP CANVAS FROM URL}

Class MapCanvasFromURL merupakan turunan dari class MapCanvas. Class ini mengimplementaiskan interface Runnable untuk menghindari deadlock pada saat melakukan koneksi HTTP.

\section{PENUTUP}

Dari penelitian ini dapat ditarik beberapa kesimpulan :

Telah berhasil dikembangkan aplikasi WMS (Web Map Services) menggunakan PHP dan database PostgreSQL sebagai sebuah server yang dapat menghasilkan peta berformat $S V G T$ dan client mobile mapping menggunakan teknologi J2ME dan SVGT Aplikasi yang dibuat mempunyai beberapa fungsi utama, yaitu download map dengan format SVGT dari server, menyimpan map ke dalam record store, menampilkan map dan juga melakukan fungsi pan dan zoom terhadap map. Fungsi lainnya adalah searching atau mencari titik tertentu pada 
map sesuai dengan permintaan user, request path ke server untuk mendapatkan jalur terpendek antara dua titik, dan set mark atau menyimpan titik-titik pada peta yang telah diberi tanda oleh user.

Telah berhasil dikembangkan sebuah server yang dapat menghitung dan mencari rute terpendek berdasarkan dua buah tempat yang ditentukan berdasarkan request dari klien, dan dapat menyajikannya dalam format SVGT.

Format data SVGT dan XML cocok diterapkan pada aplikasi WMS ini karena ukuran datanya yang kecil, terstruktur, dan akurat.

\section{DAFTAR PUSTAKA}

[1] Hui, L., 2006, Design and Implement a Cartographic Client Application For Mobile Devices using SVG Tiny and J2ME, Stuttgart.

[2] Internetnews,2006, Symbian at a Mobile Loss ,http://www.internetnews.com/wireless/article.php/358 4431, 20 Februari 2006

[3] Januar, A.M., 2003, Pengantar Scalable VectorGraphics $(S V G)$,http://ilmukomputer.com, 12 Oktober 2006.

[4] Liu, J., 2002, Mobile Map: A Case Study in the Design \& Implementation of a Mobile Application, Carleton University, Canada

[5] Luqun, L. and Minglu, L. 2004, A Research on Development of mobile GIS architecture, China.

[6] Ramsey, P., 2005. PostGIS Manual. http://postgis.refractions.net/docs/postgis.pdf. Tanggal download : 28 September 2006.

[7] Solyman, A..A., 2006, Mobile map - Technology for Application, Deutsche Gesellschaft Fuer Technische Zusammenarbeit (GTZ),

http://www.gisdevelopment.net/technology/mobilemapping /soly 2.htm, 20 September 2006

[8] W3C, Scalable Vector Graphics (SVG), http://www.w3.org/TR/SVGMobile/, 12 Oktober 2006.

[9] Wender, J.and Ronayne,D.,2003, Mobile SVG.

[10] Wiki,2006,JSR226,http://www.wiki. svg.org/jsr_226, 20 Desember 2006

[11] Wikipedia,2006.Post GIS. http://en.wikipedia.org/wiki/PostGIS. Tanggal akses : 29 September 2006.

[12] Wikipedia, 2006. Floyd-Warshall Algorithm. http://en.wikipedia.org/wiki/Floyd-Warshall_algorithm. Tanggal Akses : 2 Januari2007 